\title{
Recorregut peripatètic de recerca geològica per la comarca del Vallès Oriental: des de Caldes de Montbui al Gorg de Pèlags, al Collet de la Torre Roja, a la Serra Llisa i a la Masia del Farell
}

Josep Maria Mata-Perelló

Joaquim Sanz Balagué

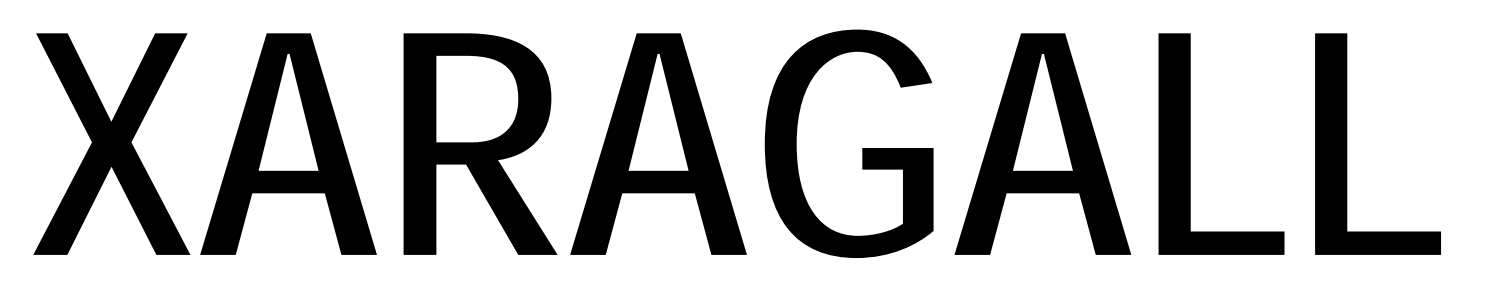

REVSTA DE CIÈNCIES DE LA CATALUNYA CENTRAL

\section{n. 1}

GENER 2015 


\title{
RECORREGUT PERIPATÈTIC DE RECERCA GEOLÒGICA PER LA COMARCA DEL VALLÈS ORIENTAL: DES DE CALDES DE MONTBUI AL GORG DE PĖLAGS, AL COLLET DE LA TORRE ROJA, A LA SERRA LLISA I A LA MASIA DEL FARELL
}

\author{
Josep Maria Mata-Perelló \\ Museu de geologia Valentí Masachs, Escola Politècnica Superior d'Enginyeria de Manresa \\ (EPSEM), Universitat Politècnica de Catalunya · BarcelonaTech (UPC), 08272 Manresa, Spain
}

Joaquim Sanz Balagué

Departament d'Enginyeria Minera i Recursos Naturals (EMRN), Escola Politècnica Superior d'Enginyeria de Manresa (EPSEM), Universitat Politècnica de Catalunya - BarcelonaTech (UPC), 08272 Manresa, Spain

Paraules clau: Sistema Mediterrani, Depressió Geològica de l'Ebre, Materials terciaris, Materials quaternaris, Patrimoni miner

\section{Resum}

Itinerari realitzat el 2 de febrer de 2014. En aquesta ocasió, el recorregut de l'itinerari discorrerà, en la seva quasi totalitat pel Sistema Mediterrani, i més concretament per la Serralada Prelitoral Catalana (la seva unitat més externa). Així doncs, la quasi totalitat del recorregut pel Farell, es realitzarà per aquesta unitat geològica. Solament en alguns dels trams propers al Farell, s'entrarà breument a la Depressió Geològica de l'Ebre, pels voltants de Sant Sebastià de Montmajor.

Per altra banda, i com ja s'entreveu al títol, el recorregut de l'itinerari discorrerà sols per la comarca del Vallès Oriental. 


\section{Objectius fonamentals}

Els objectius fonamentals que es pretenen aconseguir en aquest itinerari, es poden concretar en els següents aspectes generals:

1. Observació i descripció dels materials mesozoics (del Triàsic, exclusivament) i paleozoics (fonamentalment de l'Ordovicià i dels granits del carbonífer) de la Serralada Prelitoral Catalana, que es troben al llarg de bona part del recorregut de l'itinerari.

2. Observació dels materials cenozoics (del Paleocè i de l'Eocè), que es troben a les parts Inter mitges del recorregut de l'itinerari, i que pertanyen a la Depressió Geològica de I'Ebre. Tot i això, aquests darrers sols es veuran molt marginalment.

3. Observació de les estructures locals d'aquests materials, al llarg del recorregut de l'itinerari. Així com de les relacions entre les diferents unitats geològiques on es troben situades.

4. Observació dels diferents elements del Patrimoni Geològic (i si s'escau del Patrimoni Miner), que es vagin trobant al llarg del recorregut de l'itinerari.

\section{Antecedents}

Pel que fa al recorregut del present itinerari, cal dir que no hem sabut trobar cap antecedent bibliogràfic publicat, en relació al mateix. Nosaltres mateixos, és la primera vegada que realitzem un recorregut geològic per aquests indrets. Així, aquest recorregut podria ésser una primícia. Això si, hi ha un treball nostre, corresponent a un itinerari molt recent: Mata-Perelló (2014).

Pel que fa a la descripció de les mineralitzacions, farem esment del treball del mateix autor del present itinerari, Mata-Perelló (1991), relatiu al conjunt de les mineralitzacions catalanes.

I, finalment, pel que fa a l'estructura geològica de la zona per la qual discorre l'itinerari, farem esment dels treballs de: Guimerà et altri (1982) i de Riba et altri (1976); així com del full 392 de I'IGME (1976).

Tots aquests treballs referenciats, i d'altres, figuren esmentats per ordre alfabètic a l'apartat dedicat a la BIBLIOGRAFIA. 


\section{Recorregut de l'itinerari}

La totalitat del recorregut de l'itinerari es situarà dintre de la comarca del Vallès Oriental. És més, la pràctica totalitat del mateix es realitzarà pel terme municipal de Caldes de Montbui. Tot i això, molt parcialment, també s'entrarà al llindar amb el terme de Sentmenat, situat dintre de la comarca del Vallès Occidental.

Així, s'iniciarà al mateix poble de Caldes de Montbui (a la Plaça Taunusstein), des d'on s'anirà cap a diferents paratges del poble, situats fonamentalment a ponent del mateix. S'anirà passant pe Gorg de Pèlags, el Coll de la Torre Roja i la Serra Llisa, entre altres indrets del terme de Caldes de Montbui

El recorregut finalitzarà en arribar a la Urbanització del Farell (concretament a la Masia del Farell) des d'on es pot retornar fàcilment cap a Caldes de Montbui.

\section{Advertiments previs}

Com en altres recorreguts de RECERCA GEOLÒGICA I MINERALÒGICA... si es disposa del temps suficient, poden efectuar-se passant per totes les parades i filloles. En cas contrari, recomanem prescindir de les anomenades PARADES - CONDICIONALS.

En aquest itinerari, la totalitat del mateix es realitzarà totalment a peu, per camins de muntanya i també per alguns trams de carretera; encara que en aquest cas serà mínim.

Com en tots els altres itineraris, recomanem tenir una cura molt especial de respecte a la natura, al llarg de tot el recorregut del mateix.

\section{Descripció de l'itinerari}

Com de costum, estructurarem el recorregut de l'itinerari en una sèrie de PARADES, que tot seguit anirem veient. En cadascuna d'aquestes aturades farem un breu comentari. En cada cas indicarem, entre parèntesi, el full topogràfic on es troba l'aturada, i la designarem amb el nom d'algun topònim proper, fent esment també del terme municipal on es troba situada.

Finalment, cal dir que el recorregut de l'itinerari s'inclourà totalment dintre dels fulls $n^{0} 392$ (o de Sabadell) i 393 (o de Mataró) del "Mapa Topográfico Nacional", realitzat a l'escala 1:50.000 per I'Instituto Geográfico y Catastral de España. També s'utilitzarà el mapa comarcal del Vallès Oriental, a escala 1:50.000, editat per I'Institut Cartogràfic de Catalunya.

Així, les diferents aturades que anirem trobant al llarg del recorregut, d'acord amb el seu ordre, seran les següents. 


\subsection{Parada 1. VOLTANS DEL BOSC DEL MAS D’EN CORRÓ , (terme municipal de Caldes de Montbui, comarca del Vallès Oriental). (Full 393).}

El recorregut de l'itinerari el començarem a la població de Caldes de Montbui, des d'on ens caldrà sortir per la zona esportiva, de la Plaça Taunusstein, pel camí que es dirigeix cap al Gorg del Pèlag i cap a la Torre Roja. A poc més de $1 \mathrm{~km}$ de la sortida, abans de travessar el Torrent del Pascol, farem la primera aturada d'aquest itinerari.

En aquest recorregut, hem anat trobant afloraments dels materials granítics que apareixen pels voltants de la població de Caldes de Montbui. Efectivament es tracta d'unes roques granítiques i granodiorítiques del Carbonífer, situades dintre de la Serralada Prelitoral Catalana, tot i que ara estem en un indret molt proper al seu contacte amb la Depressió Prelitoral Catalana (o Depressió del Vallès - Penedès), per on es troba la major part de la població.

Aquestes roques granítiques es troben força alterades, havent-se format sauló, com a conseqüència de l'alteració de les mateixes. Aquesta roca d'alteració s'ha format a partir de I'alteració dels feldspats de les roques granítiques, en transformar-se en caolí, quedant així lliure el quars. (fotografia 1).

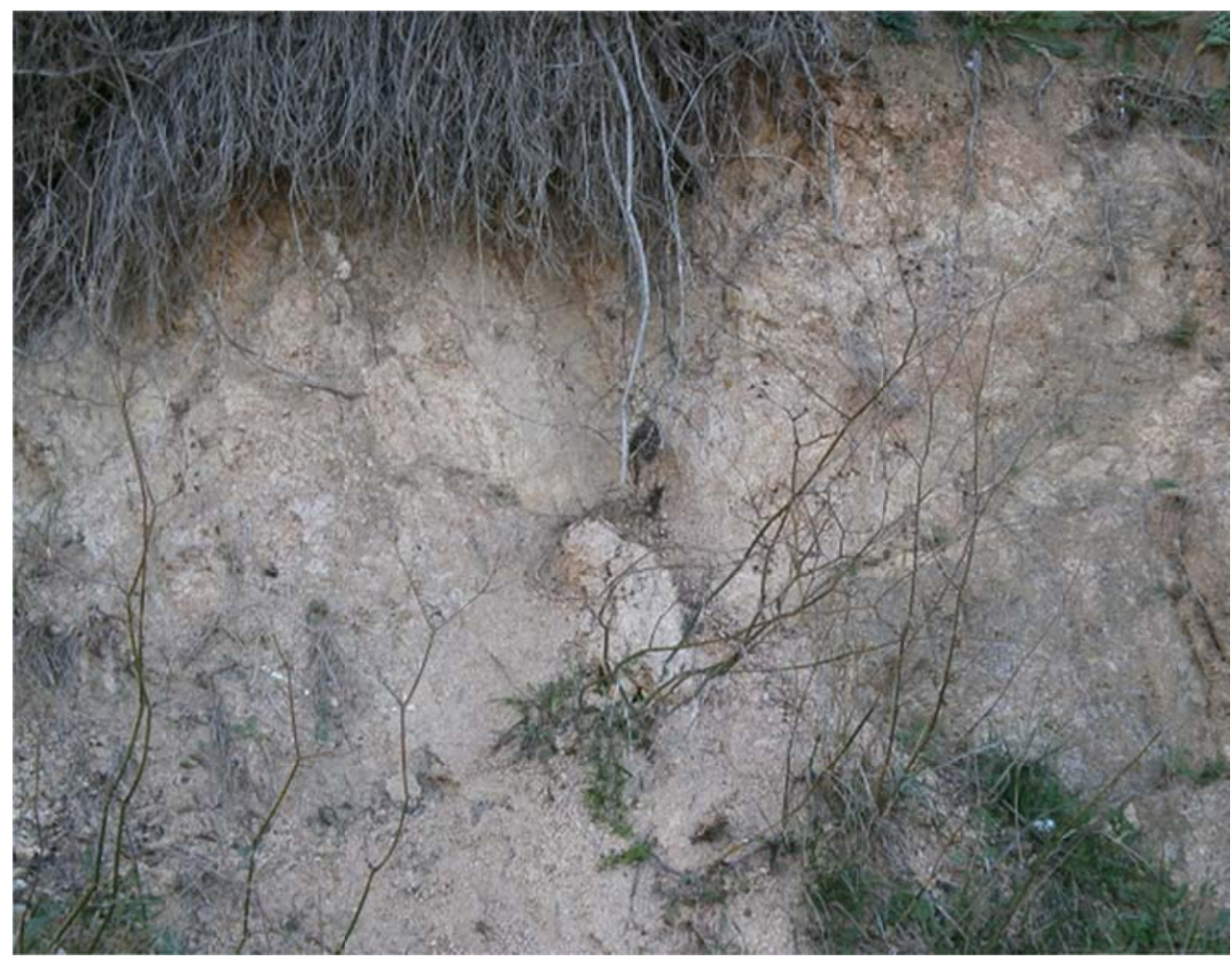

Fotografia 1. Aflorament de sauló, a la bora del camí de la Torre Roja. Caldes de Montbui 
Per últim, cal dir que aquestes roques han estat explotades prop de Caldes, a la coneguda Pedrera del Remei, tancada des de fa anys. (fotografia 2).

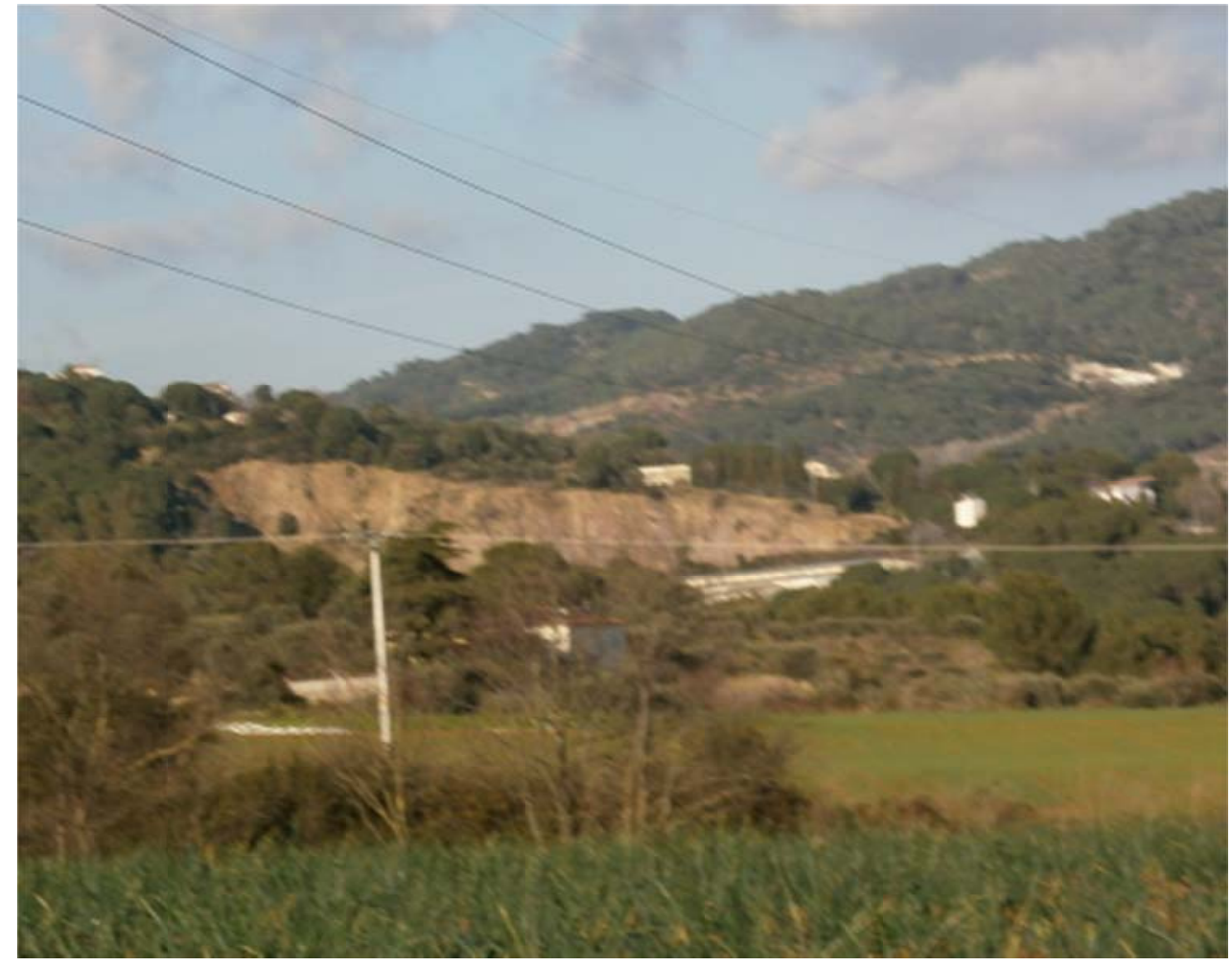

Fotografia 2. Aspecte llunyà (i borrós) de la Pedrera de granit del Remei, des del camí de la Torre Roja. Caldes de Montbui

\subsection{Parada 2. EL GORG DELS PÈLAGS, (terme municipal de Caldes de Montbui, comarca del Vallès Oriental). (Full 393).}

Després de realitzar la parada anterior, cal fer un recorregut pel camí que es va dirigint cap a ponent, cap a la Torre Roja, entre altres indrets. En trobar la senyalització del Gorg dels Pèlags, ens caldrà agafar el camí que hi condueix. La senyalització no és gaire bona i troba en un replà, amb un castellet de fusta penjat en un arbre, a la dreta del camí. En arribar-hi. caldrà fer una aturada, a uns 2 - $3 \mathrm{Km}$ de la parada anterior, fent una fillola des del camí principal, d'uns $0^{\prime} 6 \mathrm{Km}$. Cal dir que el caminet està senyalitzat amb círcols blans i negres, des del trencall a l'indret de l'aturada.

En aquest recorregut, inicialment hem trobat afloraments dels granits i granodiorites que hem vist a l'aturada anterior. Posteriorment, hem començat a trobar els materials metamòrfics de I'Ordovicià. Així, haurem vist afloraments d'esquists i de pissarres, fins arribar a l'indret de la present aturada. Aquests materials es van trobant i es fan ben palesos en travessar el torrent que baixa dels pèlags. (fotografia 3 ). 


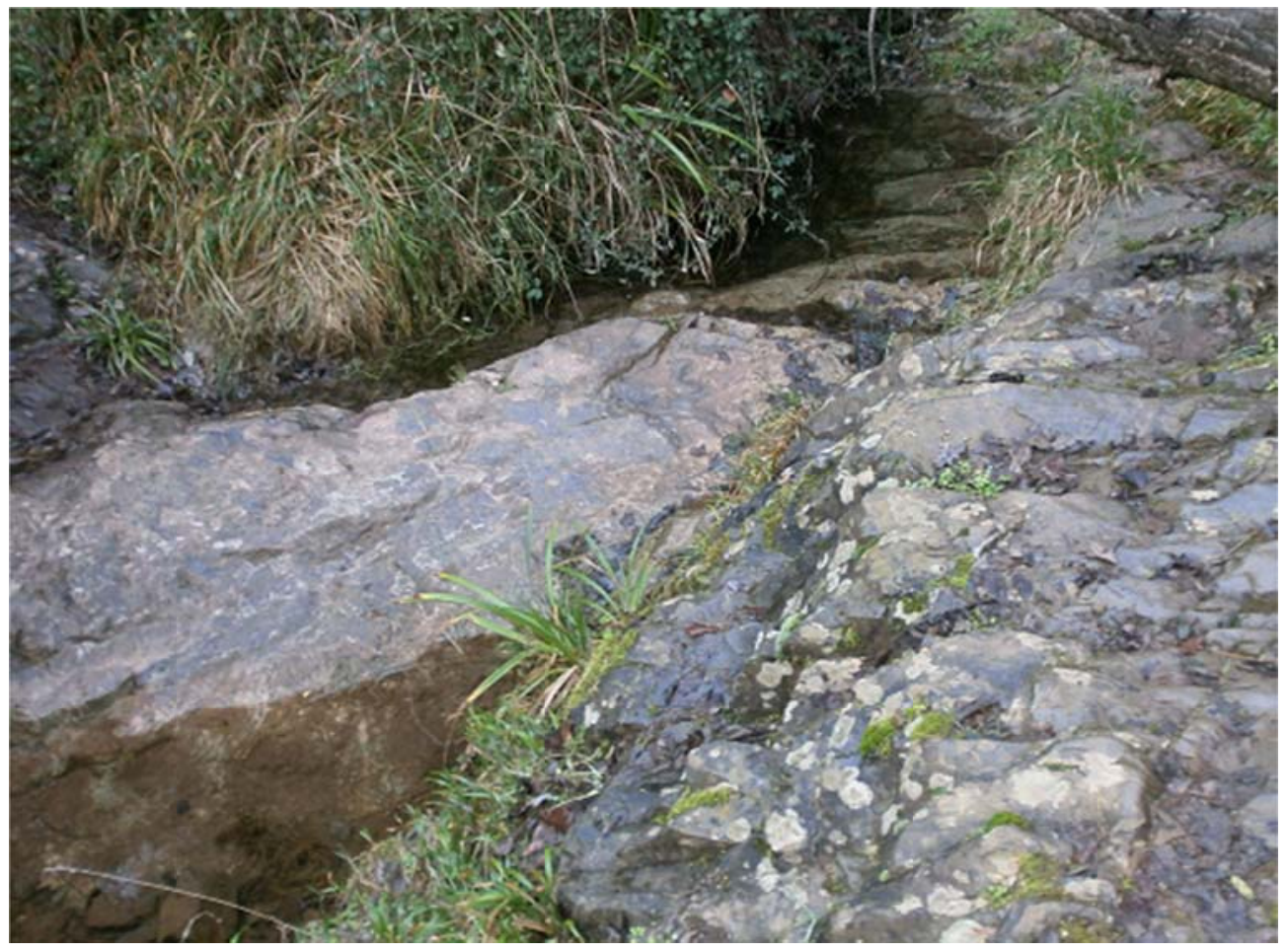

Fotografia 3. Afloraments d'esquits de I'Ordovicià, al camí del Gorg dels Pèlags. Caldes de Montbui.

Per altra banda, en aquest indret, es veuen afloraments dels nivells inferiors del Buntsandstein; concretament els conglomerats. Aquests materials triàsics, es troben discordants amb els anteriors del Paleozoic.

També cal dir que en aquest indret hi ha un paratge d'interès natural: el gorg dels Pèlags. Es tracta d'un lloc força interessant que caldria mantindré en perfectes condicions de conservació.

\subsection{Parada 3. COLLET DE LA TORRE ROJA, (terme municipal de Caldes de Montbui, comarca del Vallès Oriental). (Full 392).}

Després de realitzar I'aturada anterior, cal retornar al camí principal que condueix cap a la Torre Roja i cap al Collet de la Torre Roja, cap a on anirem ara. En arribar-hi, farem una nova aturada, després d'un recorregut ascendent d'uns $2 \mathrm{Km}$. En aquest recorregut, hem trobat un corriol que condueix cap el Gorg dels Pèlags, anant-hi cap a la part superior de l'indret.

En aquest recorregut, des del trencall, hem anat trobant afloraments dels materials paleozoics de I'Ordovicià, dels quals hem fet esment a l'aturada anterior. Així, seguint amunt, després de superar la cruilla de Roure Gros i de passar per prop de les runes de Sant Miquel de I'Arn, trobarem el contacte discordant entre els materials triàsics del Buntsandstein i els esquistos de I'Ordovicià. (fotografia 4). 


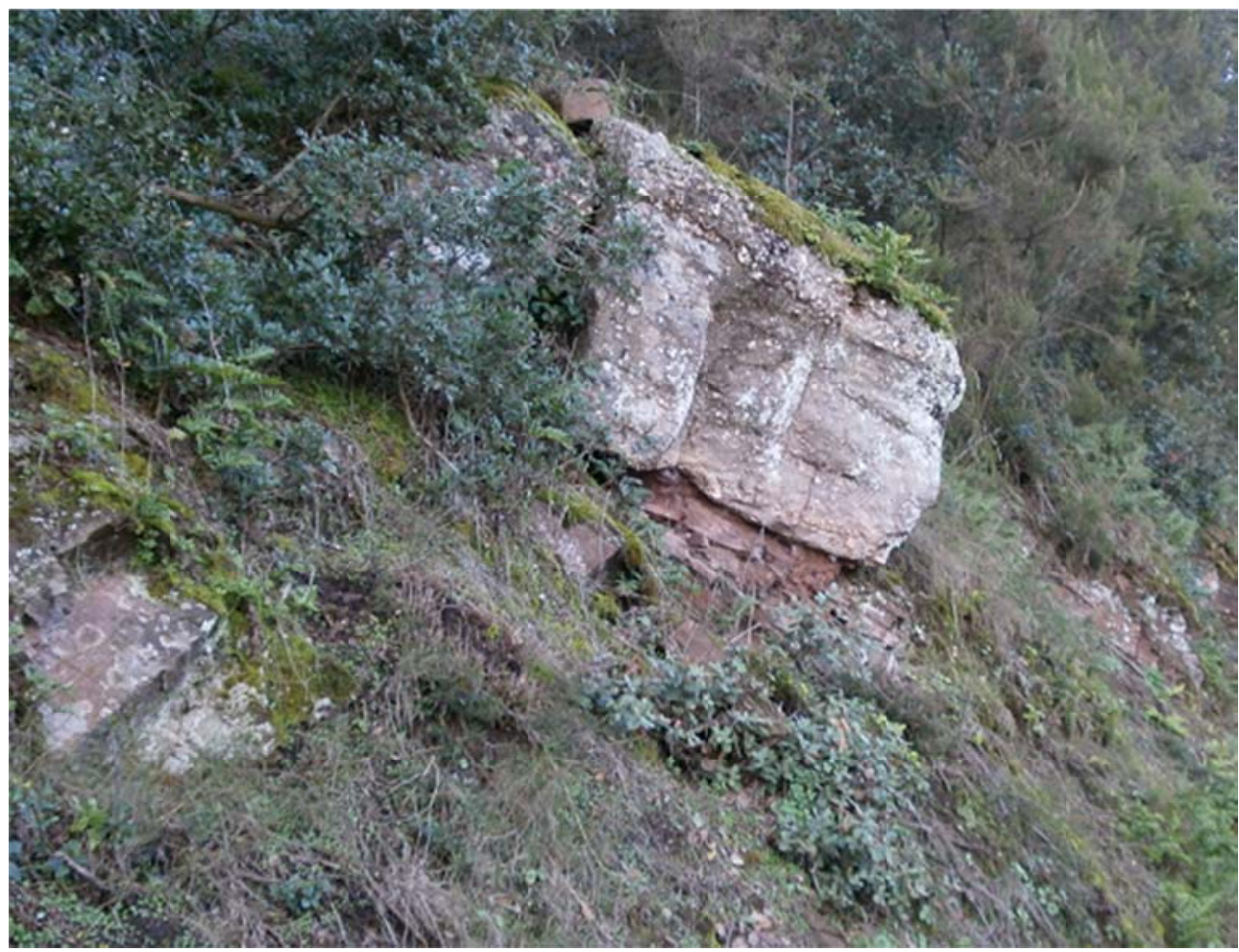

Fotografia 4. Contacte discordant entre I'Ordovicià i el Triàsic, Camí a la Torre Roja. Caldes de Montbui

A partir d'aquest indret anirem trobant afloraments dels materials triàsics del Buntsandstein. Primer trobarem els nivells dels conglomerats quarsosos; després trobarem afloraments dels nivells de gresos; i finalment les argil.lites i calcolutites roges. Aquests són els materials que afloren a l'indret de la present aturada.

\subsection{Parada 4 - CONDICIONAL. LA TORRE ROJA, (terme municipal de Caldes de Montbui, comarca del Vallès Oriental). (Full 392).}

Després de realitzar l'aturada anterior, hi ha la possibilitat de fer una fillola, anat ara cap a la Torre Roja. En cas d'anar-hi, efectuarem un recorregut inferior al mig Km des de la parada anterior.

En aquest recorregut, haurem trobat afloraments dels materials triàsics esmentats a l'aturada anterior. Aquests són també els materials que apareixen a l'indret de l'aturada.

De d'aquest indret, es pot gaudir d'un bon lloc d'observació de la Depressió Prelitoral Catalana, pels indrets on es troba situada la població de Caldes de Montbui, on hem iniciat aquest itinerari. (fotografia 5). 


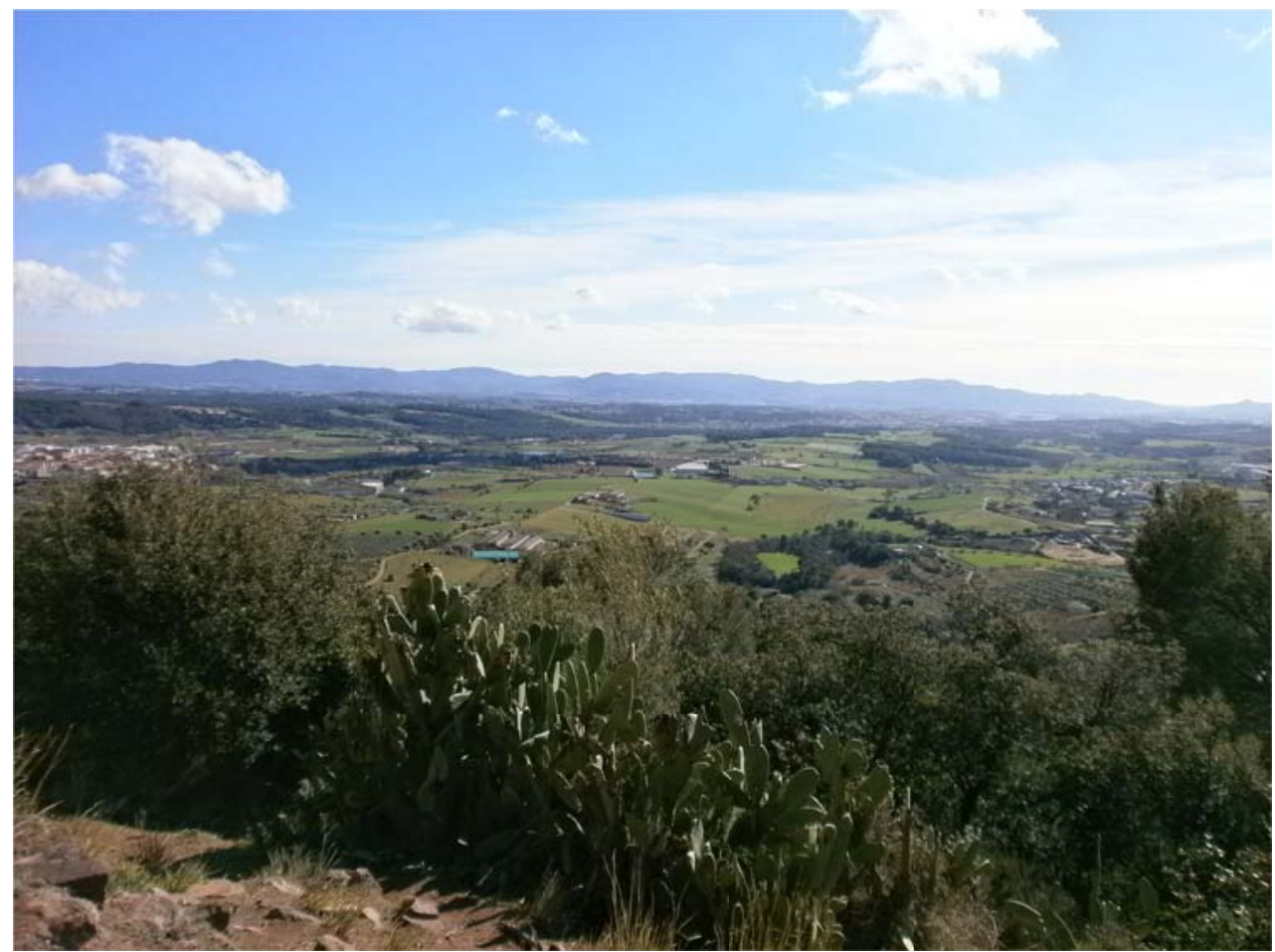

Fotografia 5. Un aspecte de la Depressió Prelitoral Catalana (Depressió del Vallès), des de la Torre Roja de Caldes de Montbui. Al fons es veu la Serralada Litoral Catalana (el Montnegre)

\subsection{Parada 5 . COLLET DEL CATALÀ, (termes municipals de Caldes de Montbui i de Sentmenat, comarques del Vallès Oriental i del Vallès Occidental). (Full 392).}

Després de fer l'aturada anterior, cal retornar al Coll de la Torre Roja, per tal de seguir amunt pel camí. Aquest ara es dirigeix cap el paratge del Collet del Català, per on farem una nova aturada en arribar-hi. Així, haurem recorregut uns $1^{\prime} 5 \mathrm{Km}$ des de l'anterior coll, i uns $2 \mathrm{Km}$ des de la parada anterior.

La totalitat d'aquest recorregut I'haurem efectuat entre els afloraments dels materials triàsics del Buntsandstein, que hem trobat a les anteriors aturades. Aquests són també els materials que apareixen a l'indret de la present aturada.

Així, la tonalitat rogenca d'aquests materials triàsics del Buntsandstein, es fa clarament palesa per tot arreu, tant pels propis afloraments, com pels camins. (fotografia 6). 


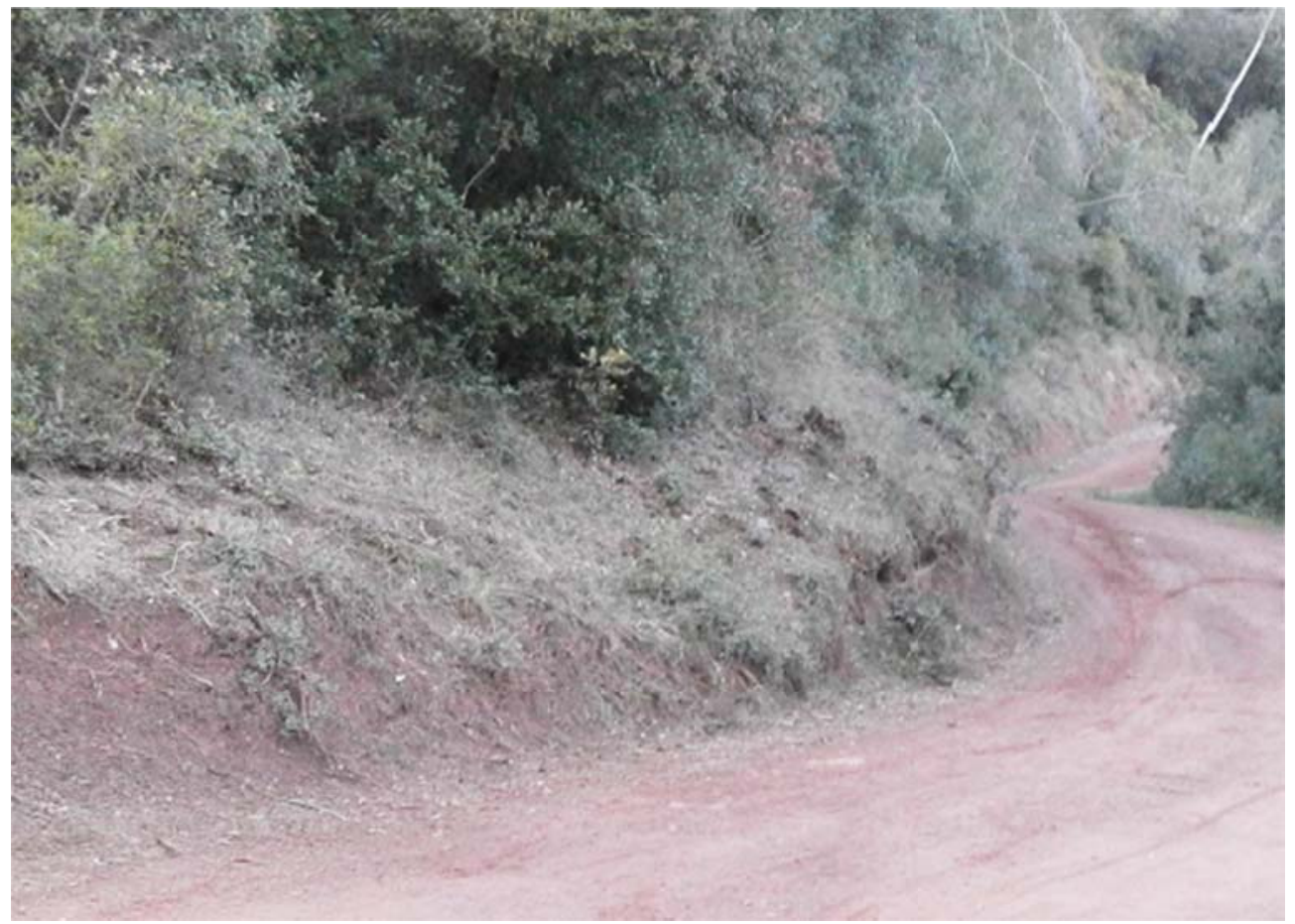

Fotografia 6. Afloraments de les lutites i calcolutites roges del Buntsandstein al Collet del Català. Caldes de Montbui i Sentmenat

\subsection{Parada 6. BOSC DEL GUANTA, (termes municipals de Caldes de Montbui i de Sentmenat, comarques del Vallès Oriental i del Vallès Occidental). (Full 392).}

Des del Collet del Català, cal seguir amunt (deixant per l'esquerra el camí que es dirigeix cap a Sentmenat). Així, seguint pel camí principal, després del recorregut d'uns $3 \mathrm{~km}$, s'arribarà a una cruïlla, des de la qual ens caldrà continuar cap al Bosc de Guanta, passant per l'Alzina de Tuies. Aquí hi ha una bifurcació, d'un camí que surt per l'esquerra, el qual es dirigeix cap a Guanta. Nosaltres seguirem amunt, però en aquest indret podem fer una nova aturada, a uns 3'5 Km de l'anterior.

En aquest recorregut, hem continuat trobant afloraments dels materials triàsics del Buntsandstein. Tot i així, ara es faran palesos uns nivells de materials carbonatats: es tracta de les calcàries i dolomies del Muschelkalk Inferior. Aquests materials, han estat explotats prop d’aquí, a les conegudes Pedreres del Pascol.

Aquestes es fan força evidents al NW d'on ara som. Des d'aquí es pot veure una de les nombroses pedreres situades en aquesta zona. I tanmateix es pot veure el seu impacte; així com l'absència de tota mena de restauració. Igualment, es pot veure la perillositat de la zona. (fotografia 7). 


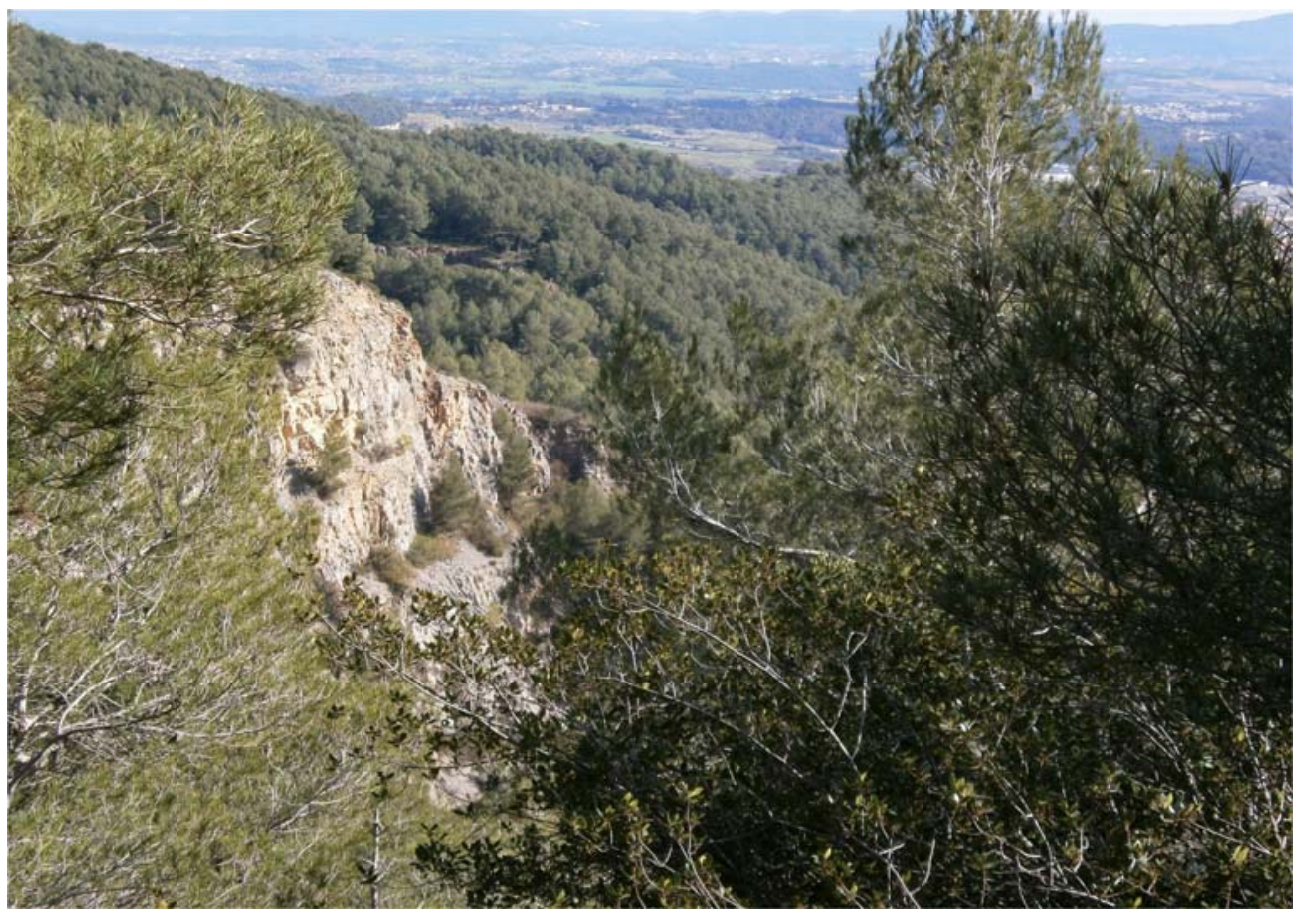

Fotografia 7. Aflorament de les calcàries del Muschelkalk Inferior a les Pedreres del Pascol. Caldes de Montbui

\subsection{Parada 7. SERRA LLISA, (terme municipal de Caldes de Montbui, comarca del Vallès Oriental). (Full 392).}

Després de realitzar l'aturada anterior, cal continuar cap amunt. En arribar a una cruïlla, ens caldrà seguir pel camí (ara molt dolent) que va pujant cap a la Serra Llisa (després deixar un camí, molt més bo) que s'adreça cap a la Urbanització del Bosc de Guanta). Així, arribarem a la Serra Llisa, per on farem una nova aturada, a uns $3 \mathrm{Km}$ de l'anteriorment realitzada.

En aquest recorregut, hem trobat els afloraments carbonatats que hem esmentat a l'aturada anterior. Es tracta dels nivells de calcàries i dolomies triàsiques del Muschelkalk Inferior. Posteriorment, trobarem els afloraments dels materials rogencs del Muschelkalk Mig, amb nivells de gresos i de calcolutites. Més endavant, trobarem afloraments dels materials carbonatats (calcàries i dolomies( del Muschelkalk Superior. Aquests darrers materials es troben encavalcant a uns nivells de gresos, calcolutites (i ocasionalment de conglomerats), que pertanyen al Paleocè i a l’Eocè Inferior. Aquests materials són els que apareixen a la Serra Llisa, per on estem ara situats. (fotografía 8). 


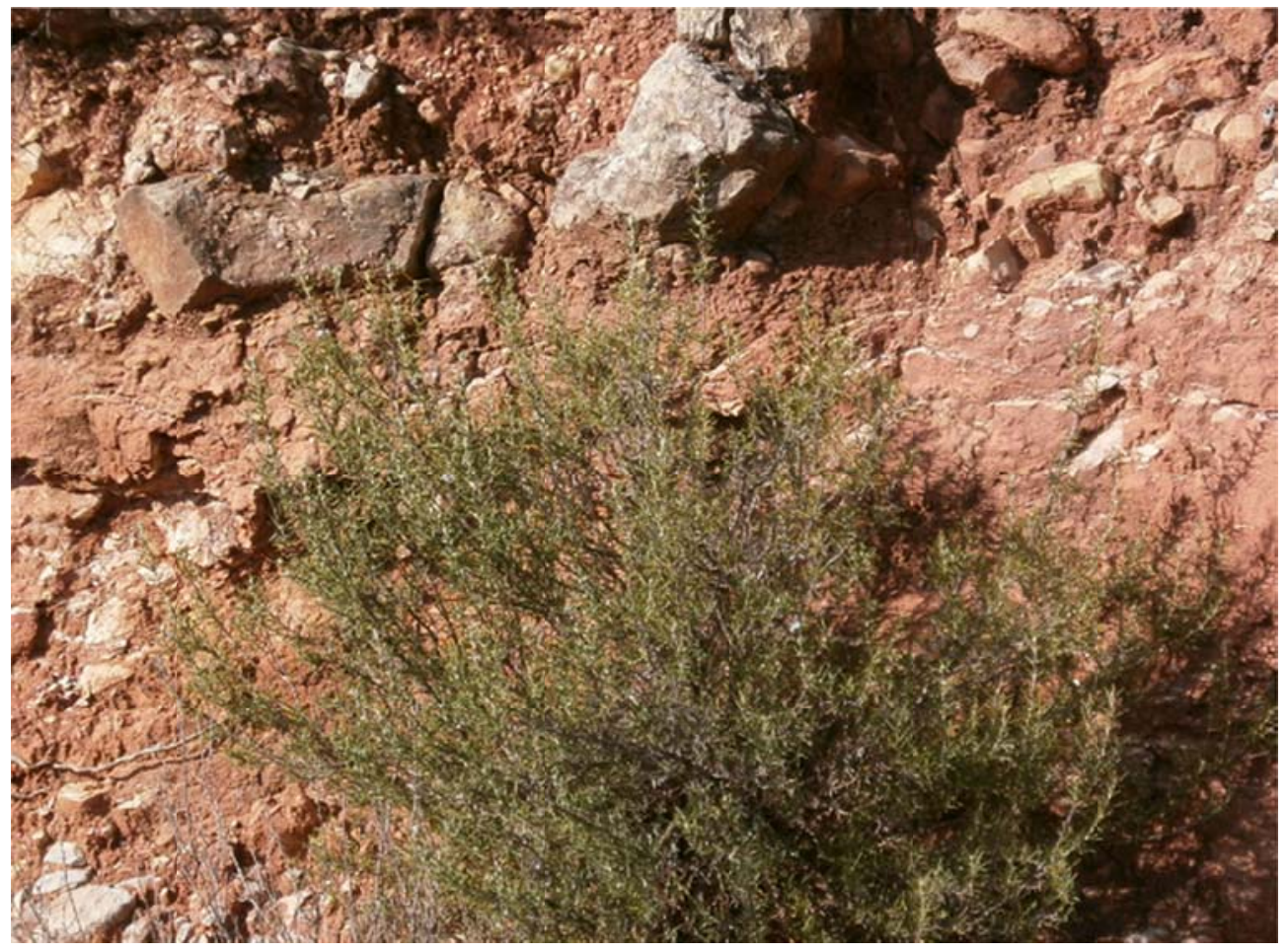

Fotografia 8. Aflorament dels materials del Paleocè (gresos i calcolutites rogenques) a lia Serra Lisa.

Caldes de Montbui

\subsection{Parada 8. TURÓ DEL VENT, (Sant Sebastià de Montmajor, terme municipal de Caldes de Montbui, comarca del Vallès Oriental). (Full 392).}

Després de realitzar l'aturada anterior, cal anar cap al Nord, amb la intenció d’arribar fins al Turó del Vent; abans trobarem el camí que hi condueix, procedent del Turó dels Tres Pins i del Turó de Sant Sebastià En trobar aquest vial, caldrà anar cap a llevant, per tal d'arribar immediatament a l'esmentat Turó del Vent, per on farem aquesta aturada, a uns $2 \mathrm{Km}$ de l'anterior.

En aquest recorregut, hem anat trobant fonamentalment els nivells rogencs del Paleocè, els quals es troben constituïts per trams de calcolutites i de gresos. Tot i així, en arribar a l'indret de la present aturada, haurem començat a trobar afloraments dels materials carbonatats del Muschelkalk Superior, del Triàsic Mig. El contacte entre uns materials i els altres es realitza per les immediacions del Turó del Vent, pels seus sectors meridionals. Aquest contacte es realitza mitjançant un encavalcament dels materials triàsics sobre els del Paleocè. (fotografia 9). 


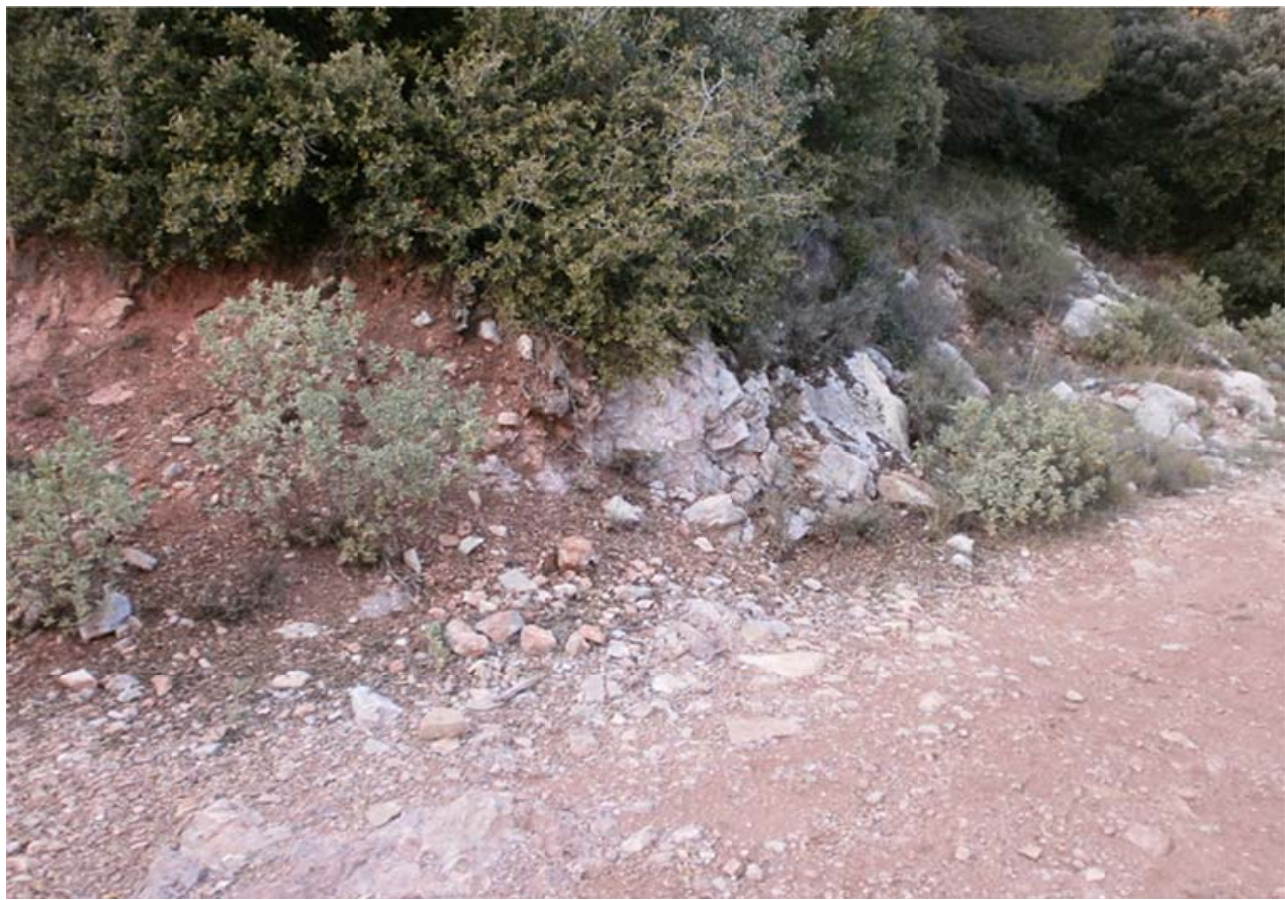

Fotografia 9. Contacte entre els nivells carbonatats del Muschelkalk Superior i les calcolutites roges del Paleocè. Al Sud del Turó del Vent. Caldes de Montbui

\subsection{Parada 9. EL FARELL, (Sant Sebastià de Montmajor, terme municipal de Caldes de Montbui, comarca del Vallès Oriental). (Full 392).}

Després de fer l'aturada anterior, cal entrar en la Urbanització del Farell, travessar-la pels seus sectors més occidentals, amb la intenció d'arribar fins a l'antiga Masia del Farell. En arribar-hi, farem una nova aturada, a menys de 1'5 $\mathrm{Km}$ de la parada anterior, aproximadlament.

En aquest recorregut, hem anat trobant afloraments dels materials carbonatats triàsics, esmentats a l'aturada anterior. Aquests materials constitueixen els punts més alts del Turó del Vent i també de les immediacions del Mas del Farell, prop d'on estem ara circulant en aquest recorregut. Per d'altra banda, en bona part del recorregut, s'ha fet força palesa la Depressió Prelitoral Catalana, per on es troben les poblacions de Caldes de Montbui i Sentmenat, entre altres.

Més endavant, en arribar a la Masia del Farell, s'han fet molt evidents els afloraments dels materials carbonatats triàsics del Muschelkalk Superior. Aquests materials (eminentment calcaries, dolomies i calcolutites groguenques) es troben intensament replegats, com es pot veure al costat de la masia. (fotografia 10). 


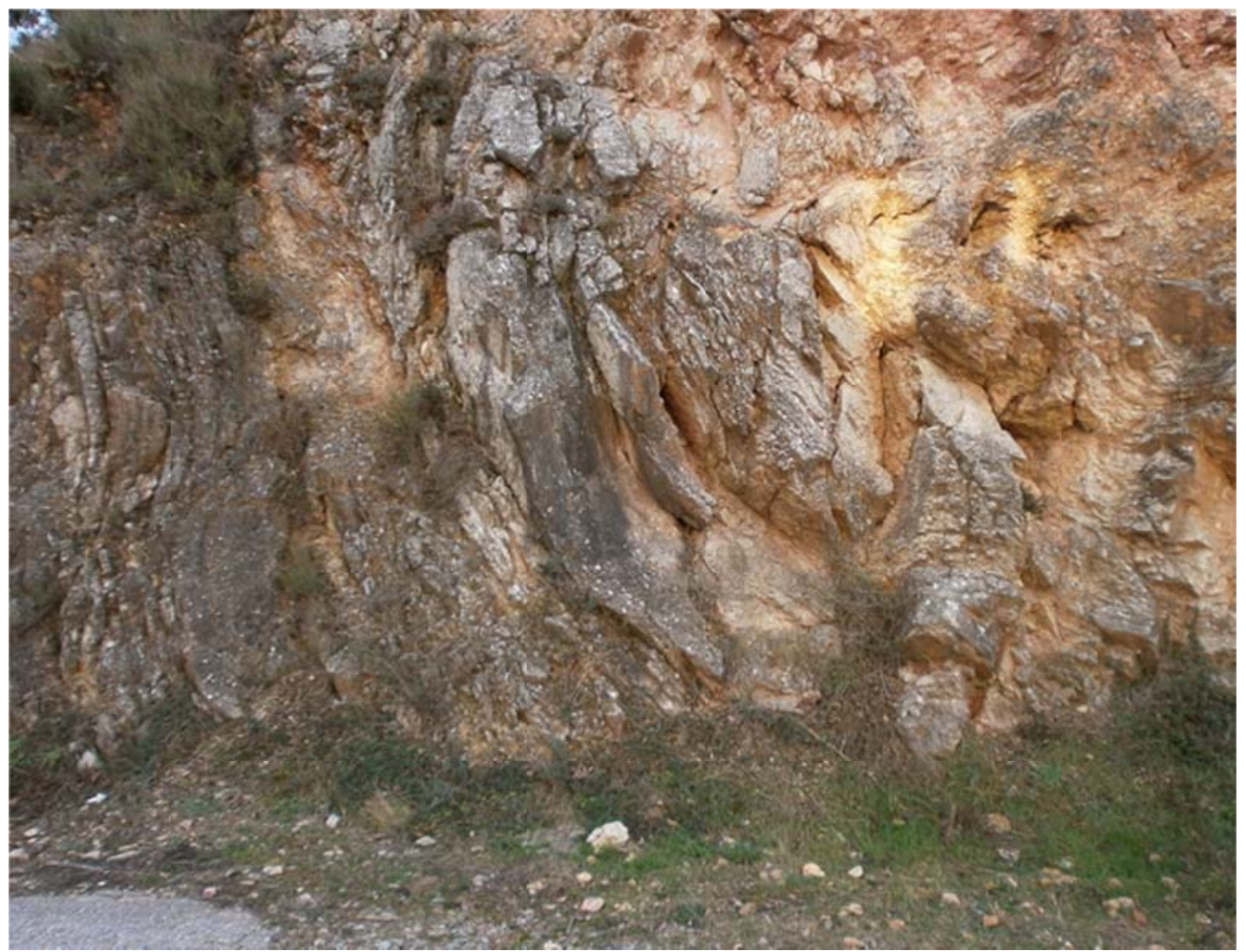

Fotografia 10. Afloraments dels materials carbonats del Muschelkalk Superior (Triàsic Mig), per les immediacions de la Masia del Farell. Aquests materials de la Serralada Prelitoral Catalana, es troben intensament replegats, en aquest indret

Si s'escau podem agafar el camí de terra que surt de la Masia del Farell, el qual es dirigeix cap a ponent, per darrera del dipòsit d'aigua. Quasi a l'inici del recorregut, es faran palesos els materials del Paleocè i de l'Eocè Inferior, que hem vist a les aturades anterior. Efectivament, en aquest indret es torna a fer palès el contacte entre els materials triàsics i els cenozoics.

En aquest indret finalitza el recorregut de l'itinerari. 


\section{Bibliografia}

GUIMERÀ, J. et altri (1992).- Geologia (II), Història Natural dels Països Catalans, Vol.2, 547 pag. Enciclopèdia Catalana, S.A. Barcelona.

IGME (1976).- Mapa Geológico de España a escala 1:50.000 (segunda Série). Hoja y memória de la hoja no 392 (Sabadell). Inst. Geol. Minero de España. Minist. Indústria. Madrid.

MATA - PERELLÓ, J.M. (1991).- Els Minerals de Catalunya. Arxius de la Secció de Ciències, t. XCIII, 442 pag. Institut d’Estudis Catalans. Barcelona.

MATA - PERELLÓ, J.M. (2014).- Recorregut peripatètic de recerca geològica per la comarca del Vallès Oriental: des de la Urbanització del Farell a Sant Sebastià de Montmajor i al Turó del Vent. Inèdit. 8 pàgines. Manresa.

RIBA, O. et altri (1976).- Geografia Física dels Països Catalans, Edit. Ketres, 217 pag. Barcelona. 